\title{
STRATEGIE KOMUNIKACYJNE STOSOWANE PRZEZ CUDZOZIEMCÓW NA LEKCJACH JĘZYKA POLSKIEGO JAKO OBCEGO NA POZIOMACH A1 I A2
}

SŁowa KLUCZOWE: STRATEGIE KOMUNIKACYJNe, NAUCZANIE JĘZYKa POLSKIEGo JAKo OBCEGO, GLOTTODYDAKTYKA

\section{STRATEgIE KOMUNIKACYJNE}

Na lekcjach języka polskiego jako obcego obcokrajowcy bardzo często zmuszeni są pokonywać trudności związane z brakiem odpowiednich umiejętności językowych potrzebnych do komunikacji. W tym celu podejmują różnego rodzaju działania językowe, które pozwalają im na realizację zamierzonych celów komunikacyjnych. Działania te nazywane są strategiami komunikacyjnymi.

Według Europejskiego Systemu Opisu Kształcenia Językowego są to:

środki wykorzystywane przez użytkownika języka w celu mobilizacji i kontroli własnych zasobów językowych oraz uaktywnienia własnych umiejętności i sposobów działania, by w najpełniejszy lub najbardziej ekonomiczny sposób, zgodnie z założonym celem i danym kontekstem komunikacyjnym, skutecznie wykonać dane zadanie.

Strategie komunikacyjne są więc istotnym czynnikiem w dydaktyce języka polskiego jako obcego. Jednak prowadzenie w tym kierunku badań empirycznych mogących przyczynić się do efektywniejszego nauczania języka polskiego może okazać się kłopotliwe, ponieważ w pracach poświęconym strategiom komunikacyjnym pojawiają się różne podejścia badawcze, a wśród nich dwa najbardziej kontrastujące: podejście interakcyjne (socjolingwistyczne) oraz podejście psycholingwistyczne (kognitywne).

W podejściu interakcyjnym, którego przedstawicielami są m.in. Tarone [1977], Dörnyei i Scott [1997], Várdi [1973], kładzie się nacisk na interakcje między rozmówcami. Strategie służą rozwiązywaniu problemów oraz obejmują próby autokorekty, 
zabiegi mające na celu zyskanie na czasie i negocjowanie znaczeń, gdy wypowiedź nie jest w pełni zrozumiała [Pawlak 2014]. Natomiast ujęcie psycholingwistyczne, które reprezentują Bialystok [1990], Faerch i Kasper [1983a], Kellerman [1991], Poulisse [1997], koncentrujesię na procesach kognitywnych. Liczba kategorii jest tu ograniczona. Nie uwzględnia się tu strategii uniku, negocjowania znaczeń i modyfikowania wypowiedzi [Pawlak 2014].

Jednak, by działania podejmowane przez uczących się można było uznać za strategie komunikacyjne, niezbędne jest spełnienie przez nich dwóch warunków. Po pierwsze, muszą być one ukierunkowane na przezwyciężenie problemu, który pojawił się podczas komunikacji. Po drugie, działania uczących się muszą być intencjonalne, a więc świadomie odwołują się do działań strategicznych [Pawlak 2014].

Strategie komunikacyjne nie powinny być traktowane jako niedostatki sprawności, ponieważ pozwalają one cudzoziemcom czynnie uczestniczyć w komunikacji mimo niedostatków kompetencji [Żurek, Molik-Kubak 2013 i ESOKJ]. Natomiast warto zastanowić się, czy wszystkie działania uczących się pozytywnie wpływająna przyswajanie języka docelowego. Badacze nie są zgodni i w tym przypadku. Podczas gdy według Tarone [1980] wszystkie stosowane strategie w dłuższej perspektywie prowadzą do użycia poprawnej formy, Fearch i Kasper [1980] wskazują, że przede wszystkim należy skupić się na działaniach kompensacyjnych, ponieważ trudno się zgodzić, że stosowanie uniku może wpłynąć na rozwój systemu językowego [Żurek, Molik-Kubak 2013].

\section{STRATEGIE WEDEUG EUROPEJSKIEGO SYSTEMU OPISU KSZTAECENIA JĘZYKOWEGO}

Europejski system opisu kształcenia językowego wyróżnia następujące typy strategii:

1) Strategie produktywne (mówienie i pisanie) oraz receptywne (rozumienie ze słuchu i czytanie ze zrozumieniem), które polegają na zastosowaniu odpowiednich schematów rozumienia na podstawie zidentyfikowania kontekstu i przy wykorzystaniu związanej z nim wiedzy o świecie;

2) Strategie werbalne i niewerbalne (wskazywanie, pokazywanie, paralingwistyczne środki wyrazu: język ciała, paralingwistyczne środki akustyczne, środki prozodyczne, paratekstowe środki wyrazu - ilustracje, fotografie, wykresy, środki typograficzne).

3) Strategie interakcyjne i mediacyjne:

Strategie interakcyjne (ustna i pisemna; bezpośrednia tzw. face to face i człowiekmaszyna) obejmują działania odbiorcze i nadawcze, dlatego w toku interakcji występują też działania produktywne i receptywne. Występują tu również strategie kolejności włączania się do rozmowy. Natomiast strategie mediacyjne (ustne i pisemne) to sposoby wykorzystywania ograniczonego zasobu środków językowych w celu przetwarzania informacji i ustalenia ekwiwalentnego znaczenia. Użytkownik języka nie wyraża własnych poglądów, jest pośrednikiem między rozmówcami, np. thumaczenia;

4) Strategie unikania i osiągnięć. 
Strategie unikania to sposoby ograniczenia ambicji, po to by dostosować wypowiedź do posiadanych umiejętności i tym samym zrealizować swój zamiar. Strategie osiągnięć polegają na sięganiu do wykraczającego ponad własny poziom możliwości i znajdowaniu sposobów na radzenie sobie z zadaniami ,z górnej półki”.

\section{KLASYFIKACJA STRATEGII KOMUNIKACYJNYCHW PODEJŚCIU INTERAKCYJNYM}

Jak zostało wspomniane wcześniej, jedną z przedstawicielek podejścia interakcyjnego jest Tarone [1977], której taksonomia strategii komunikacyjnych jest jedną z najwcześniejszych. Wyróżniła pięć głównych strategii komunikacyjnych:

1) unik

2) parafrazę

3) transfer

4) prośbę o pomoc

5) używanie mimiki i gestu.

Polskie badaczki Żurek oraz Molik-Kubak [2013] przeprowadziły badania mające na celu zweryfikowanie i zmodyfikowanie dotychczasowych klasyfikacji strategii komunikacyjnych, a podejście interakcyjne było dla nich bardzo pomocne. Rezultatem badań było zaproponowanie przez badaczki własnego modelu strategii komunikacyjnych, który opiera się na trzech podstawowych typach strategii:

1) strategie upraszczania mające na celu symplifikację przekazu na poziomach: fonologicznym, morfologicznym, syntaktycznym, leksykalno-semantycznym i pragmatycznym;

2) strategie unikania, które pomagają uczącym się „zachować twarz”, gdy napotykają trudności z przekazaniem określonej informacji;

3) strategie osiągnięć, dzięki którym uczący się realizują zamierzone cele komunikacyjne.

Badaczki zaznaczyły, że stworzony przez nie model strategii komunikacyjnych stanowi wstępną propozycję, a co za tym idzie wart jest przedyskutowania i ewentualnego przeformułowania. W swoich badaniach wykorzystałam powyższą klasyfikację strategii komunikacyjnych, ponieważ zarówno jego autorki, jak i ja należymy do zwolenników podejścia interakcyjnego.

\section{Metodologia Badań i gRUPa BadawCza}

Prowadząc różnego rodzaju kursy języka polskiego jako obcego w szkołach językowych, mam szansę być świadkiem stosowania przez cudzoziemców strategii komunikacyjnych. Wszystkie przedstawione strategie komunikacyjne miały miejsce podczas prowadzonych przeze mnie lekcji na poziomach A1 i A2. Pełniąc rolę zarówno nauczycielki, jak i badaczki, wykorzystałam jedną z metod badań empirycznych, jaką jest badanie w działaniu [Wilczyńska, Michońska-Stadnik 2010]. 


\section{STRATEGIE KOMUNIKACYJNE STOSOWANE PRZEZ CUDZOZIEMCÓW NA LEKCJACH JĘZYKA POLSKIEGO JAKO OBCEGO}

\subsection{Przykeadowe STRategie UPRaszczania}

\section{UPROSZCZENIA FONOLOGICZNE}

Cudzoziemcy upraszczali fonetycznie wypowiadane wyrazy. Bardzo często dotyczyły one trudnych do wymówienia grup spółgłoskowych, np.:

- Nicholas, skąd jest Zafar?

- On jest z Kirggisztttt. [On jest z Kirgistanu].

Poziom A1, Nigeria

Mój kolega mówi po szwetctctctc. [Mój kolega mówi po szwedzku]

Poziom A2, Węgry

Porównując język polski do węgierskiego:

My tak nie mamy po węgiesssssu. [My tak nie mamy po węgiersku].

Poziom A2, Węgry

Przyprzyprzy! [Przepraszam!]

Poziom A1, Indie

\section{UPROSZCZENIA MORFOLOGICZNE}

Uczący się wyrażali przeszłość albo przyszłość za pomocą czasu teraźniejszego lub zaimka osobowego z bezokolicznikiem, np.:

Ja uczę się języka polskiego wczoraj! Dużo, bardzo dużo!

[Ja uczyłem się języka polskiego wczoraj!]

Poziom A1, Iran

Ja napisać test jutro! [Ja napiszę test jutro!]

Poziom A1, Irak

\section{UPROSZCZENIA LEKSYKALNO-SEMANTYCZNE}

Obcokrajowcy unikali trudnych dla nich słów, np.:

- Którego ćwiczenia pan nie rozumie?

- Strona dwa siedem. [Strona dwadzieścia siedem].

Poziom A1, Francja

\section{UPROSZCZENIA PRAGMATYCZNE}

Zwracano się do nauczycielki per ty, np.:

Dlaczego jeszcze raz robisz test? [Dlaczego jeszcze raz robi pani test?]

Poziom A1, Arabia Saudyjska 


\subsection{Przykładowe Strategie Unikania}

\section{Porzucenie tematu}

Czując się niepewnie uczący się przerywali rozmowę, przed osiągnięciem celu, np.:

- Co robita pani w weekend?

- Spotykatam się z kolegami, odpoczywatam. Byt interesujacy. Jeszcze... yyy.... nie, nie.

- Co jeszcze pani robita?

- Nie, nie.

- Dlaczego nie?

- Nie, ja nie wiem, jak po polsku mówić.

Poziom A1, Włochy

\section{UNIKANIE TEMATU}

Cudzoziemcy unikali sprawiających im trudność tematów. Nie włączali się do rozmowy lub zmieniali temat, gdy nie znali odpowiednich form gramatycznych lub słownictwa.

\section{UNIK LEKSYKALNO-SEMANTYCZNY}

Obcokrajowcy rezygnowali z pewnych słów, np.:

Mam tadna sukienkę $z$... umm ... i kiedy bytam $w$ domu, to kupowatam.

Poziom A1, Włochy

\subsection{Przykeadowe STRategie osiągnięć}

\section{Parafrazowanie}

Kupiłam bilet dorosty. [Kupiłam bilet normalny]

Poziom A1, Rosja

- Jakie jest pana ulubione miejsce $w$ Lodzi?

- Mam ulubione piwne miejsce. [Mam ulubiony pub].

Poziom A1, Ukraina

Szukając różnic między dwoma obrazkami:

Na pierwszym obrazku kobieta nie ma ręki, a na drugim ma.

[Na jednym zdjęciu kobieta nie macha, a na drugim macha]

Poziom A2, Węgry

Opisując fotografię:

Tu jest wielki rower. [Tu jest motocykl]

Poziom A2, Węgry

Jest osoba, kiedy dwie inne rozmawiaja, ale nie rozmawiaja $i$ ona jest jak most dla nich. [Pośrednik]. 
- Co się Pani kojarzy z Polska?

- Biaty, czerwony. Ludzie śpiewaja na meczu.

[przyśpiewka kibiców „Polska, biało-czerwoni!’]

Poziom A1, Włochy

O wyścigach Formuły 1:

I jest té̇ flaga jak szachy. Biały i czarny. [Flaga start-meta]

Poziom A1, Włochy

\section{Przelączanie kodu}

W sytuacji deficytu językowego cudzoziemcy używali języka angielskiego, wiedząc, że wszyscy uczestnicy zajęć go znają, np.:

Dzisiaj jestem zmęczony. Miałem wiele meeting.

[Dzisiaj jestem zmęczony. Miałem wiele spotkań]

Poziom A1, Turcja

Sławna osoba jest inspiration. [Sławna osoba jest inspiracją]

Poziom A1, Turcja

\section{Prośba o POMOC}

Kursanci zwracali się z prośbą o pomoc do kolegów z grupy (częste w przypadku jednolitej grupy narodowościowo) lub do nauczyciela.

a) prośba w języku docelowym:

Jak stowo , sitowna” $w$ polsku?

Poziom A1, Arabia Saudyjska

- Kiedy mamy nastepne zajęcia?

- ,Zajęcia” to ,, lekcja”?

- Tak.

Poziom A1, Turcja

Ptywak ma specjalne okulary. Jak mówicie po polsku?

Poziom A1, Turcja

Pytanie dotyczące fragmentu tekstu: „dzisiejszy mecz”.

Dzisiejszy mecz... mecz dzisiaj?

Poziom A1, Włochy

Studentka usłyszała na lekcji słowo „chora”.

Chora, chora ... umm ... nie byta zdrowa?

Poziom A1, Włochy

Na tablicy narysowana była koperta wraz ze słowami „nadawca”, „odbiorca” oraz zapisanymi przykładowymi adresami. 
- „Nadawca”. Co robi?,,Odbiorca”. Co robi?

- Pyta pan o czasownik?

- Tak, czasownik!

Nauczyciel napisał na tablicy słowa: wysyłać i odbierać.

Poziom A1, Turcja

b) Prośba z przełączeniem kodu:

Przystojny. It means handsome, right?

Poziom A1, Arabia Saudyjska

c) Prośba o pomoc z wykorzystaniem pozalingiwstycznych środków akustycznych:

Pytanie dotyczy słowa „pociąg”, które pojawiło się w jednym z ćwiczeń.

- Pociag to... [dźwięk odjeżdżającego pociągu]?

Poziom A1, Francja

d) Prośba o pomoc z wykorzystaniem języka ciała:

Co to znaczy ,, sukces kasowy”?

Drugi student potarł palce wskazujący i kciuk jako gest oznaczający pieniądze spojrzał na mnie, żeby się upewnić, czy jego wyjaśnienie jest poprawne.

Poziom A2, Węgry

Pytanie dotyczy słowa ,bieganie”.

Bieganie... [studenta ugięła ręce i udała, że biegnie]?

Poziom A1, Włochy

Pytanie dotyczy słowa „ćwiczenie” z tekstu dotyczącego sportu.

„Ćwiczenie” to... [student podniósł dwie ręce zaczął udawać napinanie mięśni].

Poziom A1, Turcja

Rozmowa dotyczyła podróżowania. Studentka pokazała, że trzyma coś w dłoni. Następnie wskazała palcem na środek dłoni i kierując palce w prawo powiedziała: wschód i na lewo mówiąc: zachód. Potem jeszcze raz wskazała na dłoń mówiąc: To mówi gdzie. Jak po polsku?

- Kompas?

- Tak, kompas!

Poziom A1, Włochy

e) Prośba o pomoc z wykorzystaniem paratekstowych środków wyrazu:

O wyścigach Formuły 1.

Student narysował na kartce linie przypominające tor Formuły 1. Następnie wskazując palcem powiedział: Tu samochody jeżdż. Co to jest?

Poziom A1, Turcja 


\section{KOMUNIKACJA NIEWERBALNA}

Grupa ta obejmuje wszystkie zachowania pozajęzykowe, np.:

literując imię, studentka zapomniała nazwy litery $S$, więc „napisała” ją w powietrzu, po czym kontynuowała, nazywając kolejne litery imienia.

Poziom A1, Surinam

studentka opowiadając o sobie:

Ja nie... po czym udała, że wyjmuje papierosa z ust. [Ja nie palę.]

Poziom A1, Włochy

\section{Podsumowanie}

Najczęściej stosowanymi strategiami w grupie badanych były strategie osiągnięć, a wśród nich parafrazowanie oraz prośba o pomoc. Cudzoziemcy prosili lektora o podanie słowa w języku polskim na różne sposoby i wykazywali się kreatywnością, ponieważ mimo poziomu początkującego bardzo często próbowali używać jedynie języka docelowego, jakim w tym przypadku jest język polski. Dodatkowo były to: prośby z przełączeniem kodu, z wykorzystaniem pozalingiwstycznych środków akustycznych, języka ciała czy paratekstowych środków wyrazu. Kolejnymi strategiami pod względem częstotliwości stosowania były strategie upraszczania (a wśród nich uproszczenia fonologiczne) i strategie uniku. Myślę, że strategie komunikacyjne to zagadnienie, któremu warto się przyjrzeć, a w rezultacie zweryfikować, jak wpływają one na proces uczenia się oraz czy możliwy jest ich trening oraz jak (i czy w ogóle) wzbogacają komunikację.

\section{Bibliografia}

Bialystok E. [1990], Communication Strategies: A Psychological Analysis of Second Language Use, Basil Blackwell, Oxford.

Dorney Z., Scott M.L. [1997], Review Article. Communication Strategies in a Second Language: Definitions and Taxonomies, „Language Learning”, $\mathrm{nr} 47$, s. $173-201$.

Fearch C., Kasper G. [1980], Processes and strategies in foreign language learning and Communications, „Interlanguage Studies Bulletin”, s. 47-118.

Fearch C., Kasper G. [1983], Plans and strategies in foreign language comunication, [w:] Strategies in Interlanguage Communication, Fearch C., Kasper G., (red.) Longman, Harlow, s. 20-60.

Kellerman E. [1991], Compensatory strategies in second language research: A critique, a revision and some (non-)implications for the classroom, [w:] Foreign/ second language pedagogy research, Phillipson, R. i in. (red.), Multilingual Matters, Clevedon, s. 142-161.

PAWLAK M. [2014] ,Strategie komunikacyjne w nauce języka obcego - próba integracji perspektyw, „Konińskie Studia Językowe”, Konin, t. 2, nr 1, s. 11-33. 
Poulisse N. [1997], Compensatory strategies and principles of clarity and economy, [w:] Communication Strategies: Psycholinguistic and Sociolinguistic Perspectives, Kellerman E., Kasper G. (red.) Longman, Harlow, s. 49-64.

Rada Europy: D. Coste, B. North, J. Sheils, J. Trim [2001], Europejski System opisu kształcenia językowego: uczenie się, nauczanie, ocenianie, Warszawa 2001.

Tarone E. [1977], Conscious Communication Strategies, [w:] Interlanguage: A Progress Report, TESOL'77, s. 194-203.

Tarone E. [1980], Communication Strategies, Foreigner Talk and Repair in Interlanguage, „Language Learning”, nr 30, s. 417-431.

VÁRDI T. [1973], Strategies of Target Language Learner Communication: Message Adjusment, „International Review of Applied Linguistics”, nr 18, s. 59-72.

WilCZYŃSKa A., MichoŃSKA-STADNiK A. [2010], Metodologia badań w glottodydaktyce. Wprowadzenie, AVALON, Kraków.

Żurek A., Molik-KubaK G. [2013], Strategie komunikacyjne dzieci uczacych sie języka angielskiego jako obcego. Od teorii do praktyki badawczej, [w:] Sapientia Ars Vivendi. Księga Jubileuszowa ofiarowana Profesor Annie Dąbrowskiej, Burzyńska-Kamieniecka A., Libura A. (red.), Wrocław, s. 501-515. 